\title{
Kategoria pogranicza w politologii
}

Wojciech Tomasz Modzelewski, Arkadiusz Żukowski ${ }^{1}$

Link do artykułu:

http://pogranicze.uni.opole.p1/biblioteka/docs/nr1/modzelewski_zukowski1_nr1.pdf

Standard cytowania (APA):

Modzelewski, W.T., Żukowski, A. (2013). Kategoria pogranicza w politologii. Pogranicze. Polish Borderlands Studies, $n r$ 1, s. 74-75.

Podstawowe zagadnienia poddawane analizie politologicznej takie jak globalizacja czy regionalizm współwystępują z kategorią pogranicze. Zjawisko regionalizmu dotyczy m.in. obszarów przygranicznych (granicznych, nadgranicznych), tj. takich, których jedną $\mathrm{z}$ granic jest granica państwowa, zlokalizowanych po jednej stronie granicy. Stopień kontaktów między obszarami przygranicznymi zależy głównie od specyfiki granicy państwowej, w tym od stopnia jej otwartości. Widoczna jest obecnie ewolucja funkcji granicy: od bariery przestrzennej do płaszczyzny kooperacji, granica jest miejscem spotkań, zwłaszcza w kontekście globalizacji, której istotą staje się „kurczenie się/kompresja przestrzeni i czasu oraz zanikanie granic" (shrinking space, shrinking time and disappearing borders; UNDP 1999; Kuźniar 2005). Pole współpracy wokół granic państwowych tworzy obszar (region) transgraniczny (ponadgraniczny, pograniczny), transgranicze albo po prostu pogranicze. Stosunkowo rzadko w literaturze przedmiotu spotkać można odmienne podejście, gdzie przez pogranicze rozumie się „terytorialny układ społeczno-gospodarczy po jednej stronie granicy", utożsamiane ze strefą przygraniczną. Granice tak rozumianego pogranicza wyznacza pas gmin stykających się bezpośrednio z granicą państwa, lub i tych sąsiadujących $\mathrm{z}$ nimi, niekiedy powiatów bezpośrednio stycznych do granicy, lub nawet strefy $50 \mathrm{~km}$ od granicy (Kulesza 2003; Rykiel 1991).

Kategoria pogranicza nie powinna pozostawać na marginesie analizy politologicznej. Politologia jako dziedzina nauk społecznych, której przedmiotem poznania jest polityka, zajmuje się m.in. problemami polityki na rożnych szczeblach funkcjonowania instytucji publicznych, także administracji publicznej, w tym samorządu terytorialnego. Podejmowana przez samorząd współpraca transgraniczna jest specyficznym rodzajem współpracy międzynarodowej, elementem aktywności zagranicznej państwa, czyli jednym z aspektów realizowanej przez niego polityki zagranicznej (stąd nań określenia: „paradyplomacja”, „dyplomacja oddolna”, „dyplomacja społeczna”, „dyplomacja obywatelska”, „mała polityka zagraniczna”). Obecnie, widoczne jest zainteresowanie polityką oraz procesami zachodzącymi na pograniczach także ze strony innych dyscyplin naukowych, np. ekonomii (Koszyk-Białobrzeska, Kisiel 2008; Salmonowicz 1999; Teichmann 2008) i geografii (Buchnofer, Kortus 1995; Ciok, Dołzblasz, Leśniak, Raczyk 2008, Palmowski 2007). Politologia działa ponadto na styku różnych dziedzin nauk społecznych, które badają pogranicza, głównie socjologii (Gołdyka, Leszkowicz-Baczyński,

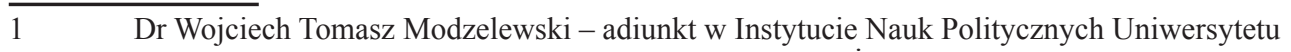
Warmińsko-Mazurskiego w Olsztynie; Prof. zw. dr hab. Arkadiusz Żukowski - kierownik Pracowni Międzynarodowych Stosunków Politycznych i Bezpieczeństwa Międzynarodowego w Instytucie Nauk Politycznych Uniwersytetu Warmińsko-Mazurskiego w Olsztynie. 
Szczegóła 1997; Kurcz i Sakson 2009; Leszkowicz-Baczyński 2001; Łukowski, Bojar, Jałowiecki 2009; Misiak, Kurcz, Sakson 2005; Sadowski 1995; Zielińska 2003; Zielińska, Trzop, Lisowski 2007) i widoczne tu jest wzajemne korzystanie $\mathrm{z}$ dorobku badawczego, powstają nawet wspólne publikacje (Pawłowska i Rykiel 2012). Bogaty dyskurs naukowy w Polsce o jej pograniczach nie doprowadził jednak do sformułowania jednolitej, dominującej koncepcji. Wyniki badań niestety tylko częściowo są wykorzystywane przez ośrodki decyzyjne.

\section{Literatura:}

Buchnofer, E., Kortus, B. (red.). (1995). Polska i Niemcy. Geografia sasiedztwa w nowej Europie. Kraków: Universitas.

Ciok, S., Dołzblasz, S., Leśniak, M., Raczyk, A. (2008). Polska-Niemcy. Wspótpraca i konkurencja na pograniczu. Studia Geograficzne 81, Acta Universitatis Wratislaviensis No. 3064. Wrocław: Wydawnictwo Uniwersytetu Wrocławskiego.

Gołdyka, L., Leszkowicz-Baczyński, J., Szczegóła, L., Zielińska, M. (red.). (1997). Transgraniczność w perspektywie socjologicznej. Zielona Góra: Lubuskie Towarzystwo Naukowe.

Koszyk-Białobrzeska, R., Kisiel, R. (2008). Euroregionalna wspótpraca i integracja na przykładzie euroregionu Bałtyk. Olsztyn: Wydawnictwo Uniwersytetu Warmińsko-Mazurskiego.

Kurcz, Z., Sakson, A. (red.) (2009). Polskie transgranicza. Wrocław: Wydawnictwo Uniwersytetu Wrocławskiego.

Kuźniar, R. (2005). Polityka i siła. Studia strategiczne - zarys problematyki. Warszawa: Wydawnictwo Naukowe Scholar.

Leszkowicz-Baczyński, J. (red.). (2001). Transgraniczność w perspektywie socjologicznej. Kontynuacje $i$ wyzwania t. 1 i 2. Zielona Góra: Lubuskie Towarzystwo Naukowe.

Łukowski, W., Bojar, H., Jałowiecki, B. (red.). (2009). Społeczność na granicy. Zasoby mikroregionu Gotdap i mechanizmy ich wykorzystania. Warszawa: Wydawnictwo Naukowe Scholar.

Misiak, W., Kurcz, Z., Sakson, A. (red.). (2005). Z pogranicza na pogranicze w świetle teorii $i$ wyników badań. Wrocław: Wydawnictwo Instytutu Zachodniego.

Palmowski, T. (red.). (2007). Pogranicze polsko-rosyjskie. Problemy wspótpracy transgranicznej z Obwodem Kaliningradzkim. Gdynia-Pelplin: Wydawnictwo Bernardinum.

Pawłowska, A., Rykiel, Z. (red.). (2012). Region i regionalizm w socjologii i politologii. Rzeszów: Wydawnictwo Uniwersytetu Rzeszowskiego.

Salmonowicz, H. (1999). Determinanty wspótpracy i integracji gospodarczej regionów przygranicznych. Szczecin: Wydawnictwo Uniwersytetu Szczecińskiego.

Teichmann, E. (red.). (2008). Battyckie i wschodnie pogranicze Unii Europejskiej. Wybrane zagadnienia. Warszawa: Oficyna Wydawnicza SGH.

UNDP (1999). Globalization with a Human Face. UNDP Human Development Report. New York: Oxford University Press.

Zielińska, M. (red.). (2003). Transgraniczność w perspektywie socjologicznej. Teorie, studia, interpretacje, $t$. 1 i 2 . Zielona Góra: Lubuskie Towarzystwo Naukowe.

Zielińska, M., Trzop, B., Lisowski, K. (red.). (2007). Transgraniczność w perspektywie socjologicznej. Pogranicza Polski w integrującej się Europie. Zielona Góra: Lubuskie Towarzystwo Naukowe. 